\title{
Nuancing the international debate on social mix: evidence from Copenhagen
}

\section{Abstract}

Whilst the political rhetoric of social mix has been similar across countries, asymmetries in their housing and planning systems and institutions owing to dissimilar underlying values, norms, and cultures has defined national and municipal practices of implementation. The purpose of this paper, based on a literature review and semi-structured interviews with government, local officials, and academics, is twofold. First, to investigate why and how city planners in the municipality of Copenhagen have used strategies of social mix in the fields of housing and land-use planning, and how these policies have evolved to deal with recurrent shortages of affordable housing. Second, to highlight the contingent nature of social mix and argue the need for more context and more sensitive analysis of social mix policies and practices. Whilst many have claimed that social mixing is a euphemism for gentrification, this paper argues that the concept can contribute to a more progressive housing and urban planning agenda.

Key words: social mix; mixed communities; housing affordability; housing policy; planning; neighbourhoods.

\section{Introduction}

The debate on social mix and mixed communities has been highly polarized, showing that: "whether social mix policies are harmless or insidious depends in part on the social and political context in which they are situated" (Arthurson, 2008: 499). Other than the influence of values, norms, and cultures that at the local and national levels shape practices of social mix, in terms of aims, strategies, and mechanisms of implementation, the theoretical foundations and methodologies deployed by scholars have also influenced results and fuelled controversies on the topic. As emphasized by Kilminster (2013), a paradigmatic example of this is the opposition between researchers who do 'critical' social theory and those who are supposedly 'value-free', that is, undertake mainstream research. Whilst the former express the struggle against what they perceive as 'domination' at the heart of their research (Lees, 2008), claiming that the rhetoric of social mix conceals "a gentrification strategy and in that a hidden social cleansing agenda" (Idem: 2451), the latter tend to adopt a more balanced tone and analysis. For example, in their studies of resident perceptions of tenure mix, Kearns et al. (2013) argue that: "most people of all tenures had positive things to say about mixing tenures, and that the spatial configuration of tenures appears to have some effect upon how positive (or negative) residents are about the desirability of tenure mixing" (Idem: 405). Similarly, in a study of the views of residents regarding tenure mix policies, Ziersch et al. (2018) emphasize the importance of context, arguing that: "there is a major difference between an area where social and affordable housing is being introduced compared with an area where it is being reduced in quantum" (Idem, 59).

To my mind, the literature that tries to equate social mix with gentrification (Lee, 2008; Rose et al. 2013) fails to account for the fact that racial and class prejudice have been the major drivers behind the construction of cities marked by residential separation of socio-economic categories, such as rich and poor or of different migrant communities. Generally, groups with low socio-economic status are over-represented in the social rented sector, which is not equally distributed across the urban space (Andersson et al, 2017). In most cases, the availability of housing and the opportunities various socio-economic and ethnic groups have to gain access to different types of housing are key elements explaining patterns of segregation (Skifter-Andersen et al. 2016). Furthermore, the argument that 
the concept of social mix has been used to justify demolition or the restructuring of large social housing estates, is only acceptable for a limited number of countries (such as the Netherlands, Australia, and the UK) as this type of policy has not been implemented extensively elsewhere. In reality, for the majority of countries the issue has been how welfare policies (such as those pertaining to land-use planning and housing policy, both responsible for the lack of mix among tenure types), have reinforced segregation, and brought about the creation of exclusive areas for those with greater economic capital versus disadvantaged areas for families with fewer resources (Le Galès \& Therborn 2009; Alves, 2016).

Drawing upon a literature review and semi-structured interviews with government, local officials, and academics, the purpose of this paper is to investigate why and how city planners in Copenhagen have used strategies of social mix in the fields of housing and land-use planning, and how these policies have evolved to deal with recurrent shortages of affordable housing and processes of sociospatial segregation. Whilst many have claimed that social mixing is a euphemism for gentrification, this paper argues that the concept of social mix can contribute to a more progressive agenda of housing and urban planning, one seeking a fair and just balance regarding housing and social interaction within cities.

The selection of Copenhagen as a case study can be justified on several grounds, both related to the nature of Scandinavian social and urban policy and to this municipality in particular, where the concept of social mix has been used as a tool to require the inclusion of a proportion of affordable housing in new private housing schemes and to tackle trends of social segregation. First, as emphasized by Bridge et al. (2014) in northern Europe, social mix has been deeply rooted in welfare policies aimed at limiting inequality, for instance, by building social housing in bourgeois areas. Furthermore, in the so-called 'Scandinavian model', which "strives to secure good living conditions for all citizens via re-distribution of wealth though social benefits and extensive housing schemes" (Jørgensen \& Æ $\varnothing \varnothing, 2008: 23$ ), the goals of social mix have been integrated into the broader agenda of welfare policies that seek to limit socio-economic and territorial inequality. Second, Denmark stands out among the most equal societies globally in terms of economic and social parameters (Alves, 2015), and even though income inequality has steadily increased in Copenhagen, along with problems of affordability, the municipality has implemented regulations to require the provision of new non-profit housing, accessible to people with ordinary incomes, in attractive neighbourhoods (such as Carlsberg, North Harbour, or Ørestad). And third, because Denmark has the lowest proportion of non-European migrants living in migrant-dense neighbourhoods, confirming the success of the policies implemented (Andersson et al 2017).

The remainder of the paper is organized in three sections. The first draws upon a literature review on the concept of social mix and mixed communities from an international perspective. Among other issues, this section briefly discusses the reasons for the lack of consensus in the debate around social mix, such as those related to the operationalization of the meaning of social mix and mixed communities in terms of policies and practices and the evaluation of their potential effects. It also discusses the concept of class, as it is quite pertinent to debates on social mixing. The second section, which is also primarily based on a comprehensive literature review, aims to discuss how the main features of the Danish welfare state and housing policy are closely intertwined with social mix policies. The third part of the paper discusses the main results of the semi-structured interviews that were conducted with key stakeholders and academics in Copenhagen. Drawing upon participants' views and experiences, this section discusses the meanings, assumptions, and rationales driving the implementation of social mix in the Danish capital. Details concerning the research methodology are presented, as well as a reflection on the limits of the sample. 


\section{The theoretical foundations of social mix: On the lack of consensus}

Several national and local European governments have made a commitment to supporting the development of mixed communities. Such advocacy has been articulated through planning, housing, and regeneration policies and has involved collaboration with a number of public, private, and third sector organizations. Whilst at the political level ideas of social mix have been seen as a solution to processes of socio-economic and ethnic residential segregation, at the academic level they have raised several epistemological concerns related to their policy goals, ideological assumptions, operational tools and effects. Results of social mix policies have been controversial, with a notable lack of consensus among observers with respect to: i) the ambiguous meaning of social mix and mixed communities; ii) the diversity of policies and practices, and iii) the varied effects of social mix.

The concept of social mix

The concept of social mix has been understood in a variety of ways. It has been defined as a heterogeneous population structure (in terms of occupation, household structure, ethnicity, and age group), and housing structure (housing tenures, e.g. home-ownership, private rental etc., types, and prices) usually at the neighbourhood level. Whereas most scholars discuss the concept of mixed communities with reference to both ethnic and income parameters, others discuss it in relation to tenure mix, noting that the relationship between social and tenure mix is contingent upon specific local contexts, for example, economic circumstances (Holmqvist \& Bergsten 2009), and is not always certain. In this regard, Fainstein (2005) asks: "does a mix of uses along with a mix of structures produce social diversity?" (Idem: 9). In countries with dualist housing rental systems (e.g. Portugal, the UK), where the social housing rental market is formulated as a safety net for the poor, the development of mono-functional housing projects tends to be associated with the segregation of social classes, with neighbourhoods being characterized by physical and social homogeneity (Alves, 2017a). The literature review also reveals a lack of consensus regarding the definition of what a 'good' social mix is and what kinds of social mix are required (e.g., percentages and types - such as income, class, age, ethnicity, tenure). As Monk et al. (2011) caution: "is it income mix, ethnic mix, social mix or tenure mix? How mixed should the mix be? And at what spatial scale?" (Ibid, p. 36).

In this paper I use the concept of social mix to refer to "planning efforts that strive for some combination of the following: balancing the socio-economic variance of residents and a mix of different housing tenures (public and private rentals, owner-occupation)" in a spatially defined area (Fincher, et al., 2014, p. 16). The term refers, therefore, to: "public policies that 'explicitly' but not necessarily exclusively aim to affect the demographic, social or ethnic composition of residential districts in such a way that cities become 'less segregated' than they would have been had such measures not been taken" (Andersson et al., 2010: 238). I am, therefore, interested on the one hand in discussing the goals, rationality, and justification that underlie programmes of social mix, and on the other, in the way social mix, as an intervention programme, has been implemented in different policy domains (e.g. spatial planning, housing) to address problems of socio-spatial segregation.

\section{Policies and practices of social mixing}

To begin with, it is important to note that, whilst the idea of social mix is not new, its application in the context of urban policy is relatively recent and has been restricted to only a few countries 
(Bridge et al., 2014). Whilst Arthurson et al. (2015) claim that there are two predominant perspectives around the policy interpretation of social mix - one claims that in so far as it promotes more social interaction across groups, social mixing is a remedy for social exclusion therefore a tool for social inclusion; the other (the dominant narrative) argues that 'social mix' is a euphemism for state-led gentrification, and therefore equates with gentrification. Skifter-Andersen (2016) adds a third, arguing that policies of social mix have been used as a strategy to prevent and counteract processes of segregation and urban decay, that is, the concentration of less well-resourced families and the inter-generational transmission of disadvantage. The results presented in this paper suggest a fourth one, the use of social mix as a medium within formal institutions of planning and housing to foster the delivery of more affordable housing. It shows that even in countries such as Denmark where instruments of inclusionary housing have not been made available at the national level, planners and other groups of actors at the local level (e.g. from the public and non-profit sectors) have used social mix as a principle to require a supply of land for the provision of a proportion of new homes at affordable and not-for-profit rents.

Strategies of social mix have varied significantly in their rationales, purposes, and modes of implementation (Rose et al. 2013). For example, whilst some countries have launched national programmes for the restructuring of large and mono-tenure housing estates, others have opted for comprehensive urban regeneration programmes to make neighbourhoods more attractive and socially diverse. In France (Lelévrier, 2013), the Netherlands (Bolt \& van Kempen 2013), and the United Kingdom (Morrison \& Burgess, 2014), the goal of combating socio-spatial segregation has been on the national political agenda for many decades and has involved the partial demolition/refurbishment of some buildings in social or non-profit housing estates, and regulations that stipulate that a percentage of all new housing must be set aside for affordable housing, in the attempt to create a greater mix of housing tenures and income values. One of the main shortcomings of these policies, according to critical literature (Musterd \& Ostendorf, 2012; Lees, 2008), has been the reduction of affordable housing for low-income people (as new public housing tends to be associated with higher costs, therefore rents), and an area-based approach that limits attention to a certain number of neighbourhoods: "where large sums of money are spent to demolish part of the housing stock, even stock of good quality, and to rebuild the plots with other housing, better suited to other social strata" (Musterd \& Ostendorf, 2012, p. 469).

\section{On the effects of social mix}

Scrutinizing the relationships between neighbourhood attributes and individual outcomes, Galster and Friedrichs (2015) claim that there is enough empirical evidence to justify the goal of social mix on the grounds of improving the absolute well-being of the disadvantaged. They argue, plausibly, that causal evidence from Europe and North America indicates that disadvantaged individuals are i) harmed by the presence of sizable disadvantaged groups concentrated in their neighbourhoods, and ii) assisted by the presence of more advantaged groups in their neighbourhood, probably due to positive role modelling, stronger collective control over disorder and violence, and the elimination of geographic stigma, as opposed to cross-class social ties (Ibid, p. 175). Despite the alleged existence of such evidence, the link between social mix and social relations has been challenged (Wessel, 2009; Selim, 2015; Tersteeg \& Pinkster, 2015). In this regard, it has been noted that the residential proximity between households or groups belonging to different social classes can favour contact, but this does not necessarily reverberate in subsequent social cooperation and a positive flow of capital from the middle class to the lower class (Heringa et al., 2017). It has been observed that in urban areas with some social mix, for example, where urban renewal processes have attracted a middle 
class (Malheiros et al., 2013), or in areas where processes of urban decay have attracted families with fewer resources (Alves, 2017a), the symbolic and/or cultural distance associated with linguistic differences and lifestyles tends to be more important than the fact that people live nearby. This is the conclusion presented by Colomb (2007) in London where, allegedly, the mix of housing tenures, which has resulted in relative physical proximity between different socio-economic groups, does not ensure proximity in public spaces, schools, services, and shops. From another perspective, whist some scholars emphasize the potential limitations of living in a poor neighbourhood with respect to the extent and quality of networks, health outcomes, educational achievement etc. (see Manley \& van Ham, 2012), others claim that enclaves of households belonging to the same social group (ethnicity, income etc.) are not a problem in itself, namely when they are perceived positively by residents and favour relationships of solidarity and the preservation and affirmation of cultural, ethnic, and religious identities (Young, 2002).

Following Bourdieu (1999), Wacquant et al. (2014), who has not written on social mix but on the role of the state as an agent of socio- and spatial stratification, criticizes the state for relegating certain social groups to inferior positions, conditions, or locations within the city, and for using discriminatory concepts and narratives, such as ghettos, that have further stigmatized deprived territories and inhabitants (Wacquant et al., 2014).

Because the research on social mix has involved various research questions, has been carried out in various political and socio-economic contexts employing differing methodologies, results have varied considerably (see Ziersch et al. 2018). Contrasting results can even be found in similar national contexts and regarding similar issues. For example, regarding typologies of areas where these policies have been implemented in the UK. Whilst Loretta Lees (2008) claims that "social mixing is a one-sided strategy that is seldom advocated in wealthier neighbourhoods" (Lees, 2008, 2460), Monk et al. (2011) claim that: "this policy has introduced affordable homes into wealthier, more expensive areas where they would not have been delivered through 'traditional' means (built by housing associations with government grants)" (Monk et al. 2011, p.37). The debate on social mix has also demonstrated the relevance of methodologies for results gleaned from empirical research. On this issue, Jensen (2016) notes that, whilst quantitative research maintains that ethnically diverse neighbourhoods lack solidarity, trust, mutual cooperation, and friendship, and that diversity has negative effects on social interaction, qualitative studies of multi-ethnic neighbourhoods generate different and less problem-focused images of neighbourhood relations that reveal various forms of informal daily contact. The empirical results of the research also show that the very concepts used by researchers and the way they are interpreted or valued by respondents may also affect these results (Jensen 2016).

\section{The link between social class and social mixing}

The concept of class, which remains important in sociology and is pertinent to debates on social mixing, has evolved over time. Pierre Bourdieu's theory of social differentiation and his analysis of class and power demonstrates the relevance of three types of capital, that is, economic (wealth and income), cultural, and social (Savage et al. 2015). It also emphasizes the relationship between the position of individuals in social space and its spatial distribution in geographical space, as the latter is also characterized by different volumes and compositions of resources or assets. The relationship between class formation, social power, and power over space is emphasized by Wacquant (2018), who reminds us, that by using strategies of control over neigbourhoods, the higher bourgeoisie produces and reproduces inequality. 
"The elective seclusion of the dominant class in reserved upscale quarters is a decisive basis for its power. This segregative isolation is strengthened by group-specific institutions, such as society balls and social clubs that work alongside exclusive schools to effect rigid class closure. [...] Spaces reserved by and for the high bourgeoisie are major vectors of social reproduction" (Wacquant 2018, pp. 101-102).

In the debate on social classes as position-practice relations ${ }^{1}$ (Giddens 1984: 85), and neighbourhoods as a 'cluster of class situations' (Allen et al. 2007), it has been demonstrated that "social inequality takes on a determinately spatial form", and this form affects opportunities for social contact and interaction across contrasting socio-economic circumstances (Warr et al. 2017, Alves, 2016). The way neigbourhoods are constructed and managed, through the influence of planning and housing legislation and practices, influences not only aspects of class formation and fissure, but also aspects of identity, mobility, lifestyles, and social networks.

There is abundant research on the impacts of negative segregation generating sites of concentrated place-based socio-economic disadvantage, but there is also abundant research on the negative impacts of place-based operations that dismiss residents' critical perspectives and needs, for example, the need for affordable housing and support (Bolt, 2009). It is crucial to understand that knowledge is context-dependent and cannot be separated from either the context in which it is developed or its purposes. What works, for whom, and why has to be understood in the context of social and spatial relations.

Based on a comprehensive literature review, the next section discusses the main features of the Danish welfare state and housing policy in relation to urban segregation, social mix, and affordable housing provision.

\section{Issues of segregation and social mixing in Denmark}

Ideas of social mixing as a normative ideal to guide urban policy have recurred throughout the history of urbanism (Sarkissian, 1976). In 1948 the so-called 'Finger Plan', drafted to guide the expansion of Copenhagen, recommended that housing and commerce should be positioned along radial roads and railways, while retaining large green wedge areas towards the centre of the city. As part of the attempt to remedy the widespread housing shortage and clear slums, the plan advocated the construction of new housing estates with single family homes and council housing estates in the suburbs. In the north developed the upper and upper middle class suburbs, to the west, with the provision of non-profit housing, developed working-class suburbs. An array of contextual driving forces, related, for example, to the 1973-74 oil crisis and the de-industrialization of Copenhagen, led in the 1980s and 1990s to a shift in urban policies that, from a steering role focusing upon regulation, became increasingly focused on boosting the competitiveness of the city and the coordination of sectoral policies (Galland, 2012). This represents a shift from an agenda of redistribution, in which principles of equal provision and accessibility to welfare services are central, to one of growth and market-oriented policies (Carter et al., 2015; Hansen et al., 2001). Larsen and Hansen (2008) identify several entrepreneurial public investments designed to boost the

\footnotetext{
${ }^{1}$ Giddens claims that: "from a historical and empirical point of view, one can only very rarely speak of fixed classes and class boundaries; for the most part, what we find are variable 'stages' of class formation, influenced both by a society's mode of production as well as the degree of intergenerational mobility, which is potentially subject to change" (Joans \& Knobl 2009: 288).
} 
competitiveness of the Danish capital, for example, the development of $\varnothing$ restad on the island of Amager, the construction of the Øresund Bridge and tunnel between Denmark and Sweden, or the redevelopment of run-down neighbourhoods, such as Vesterbro, traditionally a working-class area.

The prevalence in Denmark of a social democratic ideology, combining a dynamic private market and efficient public regulation in a wide array of sectors (Jørgensen \& $\mathbb{E} \varnothing \varnothing, 2008: 24)$, including economic redistribution and housing, explains the existence of a healthy supply of non-profit rental housing that is not restricted to low-income families and supports a socio-economic mix not found in many other countries.

In 2017 the Danish population numbered 5,781,190 people. Analysis of the distribution of occupied dwellings (dwellings with registered population) by tenure between 2004 and 2017 throughout Denmark shows the preservation of the balance between rental and owner-occupancy, with only $50 \%$ of all Danes living in owner-occupied housing in 2017 (see Figure 1).

Figure 1 - The distribution of occupied dwellings (dwellings with registered population) by tenure in Denmark, 2004-2017. (Source: Statistics Denmark, www.dst.dk/uk).

While a study by Alves (2017b) emphasizes this striking feature of the Danish housing system (Alves, 2017b: 24), Jensen and Stensgaard (2016) recall that the housing market in Copenhagen is in several ways significantly different from the rest of Denmark ${ }^{2}$, with a much higher proportion of renters in the capital. In Copenhagen in 2014 , only $18 \%$ of the housing stock were owner-occupied, private rentals stood at 19\%, private cooperative housing (private co-ops, in Danish andelsboliger) represented $33 \%$, and social housing $20 \%$ (Jensen \& Stensgaard 2016).

Figure 2 - The distribution of occupied dwellings by tenure in Denmark and Copenhagen in 2017. (Source: Statistics Denmark, www.dst.dk/uk).

The public housing sector (almene boliger) comprises housing owned and managed by private nonprofit housing associations. Each non-profit housing association owns a number of housing estates, and each section (social housing estate) constitutes an independent economic unit with its own economy, planning, and board appointed by and chosen from the residents of the section (Kristensen, 2002). The construction of this housing is subsidized by national and local governments that in turn have the right to assign families in acute housing need up to $33 \%$ of total vacant dwellings in the case of Copenhagen.

The mechanisms that have led to the conversion of private rented housing and municipal dwellings into cooperatives are explained by Skifter-Andersen (2012), while the reasons for the escalation of prices for second-hand co-operative shares, which rose by $110 \%$ between 2000 and 2005, can be found in Jardar Sørvoll and Bo Bengtsson (2018). It is worth recalling that Danish housing prices increased steadily in the 1990s, and the 2000s saw substantial increases until the global financial crisis of 2007. Subsequently, housing prices declined but in recent years prices have increased, especially in Copenhagen.

Larsen and Nørgaard (2003) identify two key generations of Danish urban renewal policy. The first, in the 1930s and 1940s, which mainly focused upon issues of physical renovation, played out in two

\footnotetext{
${ }^{2}$ Throughout Denmark, the private rented sector accounts for $27 \%$ of the total stock, with housing benefit covering around $32 \%$ of households in this housing market (Cole \& Etherington, 2005: 79), and 20\% of all stock is owned by housing associations, the main providers of affordable housing for low and middle-income families.
} 
different stages. The first phase was predominantly a slum clearance approach to improve housing and urban conditions through the demolition of older and poor-quality housing in built-up inner areas, and the creation of housing with more open spaces (eg. in the central district of Nørrebro). The second phase, as a reaction to criticisms raised by the first was mainly driven by architectural conservation and the participation of residents in the planning process (Larsen \& Nørgaard 2003). The second key generation of Danish urban renewal policy, between 1997 and 2003, emphasized issues of urban governance, both in policies that aimed to boost Copenhagen's competitiveness (Larsen \& Hansen 2008), and those that aimed to promote social welfarism and spatial Keynesianism (Olsen \& Carter, 2017). Regarding the latter, in the 1990s the government established an 'Urban Committee' involving ministers from different ministries and departments to develop the Kvarterløft ('neighbourhood uplift') programme to promote equal development across the city and the fight against 'ghettoization'. The Kvarterløft programme was a selective area-based initiative focusing upon neighbourhoods with a higher concentration of underprivileged residents, such as unemployed individuals or those with weak connections to the labour market, health problems etc. SkifterAndersen $(2002,776)$, who was involved in the evaluation of this programme, claims that the most important Kvarterløft measures were associated with 'physical renovation and rent decreases', as the effort to improve the physical condition of neighbourhoods was associated with economic measures to avoid displacement following the renovation of buildings. The programme, which involved an overall investment frame of around 160 million euros distributed among 12 districts or projects, an investment shared between national level bodies and municipalities, promoted principles and methods of democratic decision-making and participatory democracy and collaboration in the Danish housing sector (Larsen \& Nørgaard, 2003; Engberg \& Larsen, 2010). As regards strategies of social mix, regeneration plans across the country have shown remarkable differences regarding their (social mix) goals:

"In the projects in Randers and Kolding the goal was to avoid gentrification of the area and thus keep a mixed social composition. On the other hand, in Avedøre Stationsby with only social housing the ambition was to attract more well-to-do citizens. This was also the ambition in a similar area in Aalborg, while the areas in Copenhagen lay in between in that respect" (Munk, 2007, p. 10).

Formal evaluation of the Kvarterløft programme has shown that the initiative prevented further negative escalation of the social, physical, and economic conditions of the estates, and further concentrations of marginalized Danes and immigrant families (Skifter-Andersen, 2002: 776). It also showed that the strategy to reduce segregation was, however, difficult to implement (SkifterAndersen, 2002, pp. 783). Using Danish longitudinal data on the individual level for 1989-2006, Christensen (2015) confirms that these area-based interventions had no significant effect on social blending, whether in respect of educational background, employment mix, income mix, or ethnic mix, namely in most marginalized residential areas.

In Copenhagen, the Policy for Disadvantaged Areas and the Municipal Planning Strategy (2014) have emphasized the municipality's commitment to training, employment, and social and cultural/ethnic encounters. The official discourse is that one of Copenhagen's greatest strengths is its diversity, but the differences that exist between its various districts should not undermine individual and collective opportunities. To tackle area deprivation, Local Revitalization Plans have been developed to provide extra resources and better cross-sector cooperation, and a new system of flexible allocation for vacant dwellings which aims to contain the flow of vulnerable households into disadvantaged neighbourhoods ${ }^{3}$ (Nielsen et al. 2016). In the actual context of Copenhagen's population growth, in

\footnotetext{
${ }^{3}$ In certain neighbourhoods, vacant dwellings are now prioritized: i) for students and young employees under 35 years old and working more than 25 hours a week; ii) employed people over 55 years old who wish to move
} 
which flexible allocation rules have increased the difficulties the unemployed face in gaining access to housing, the municipality has set a political ambition to provide at least $20 \%$ of non-profit housing in the new development areas, and increase support for non-profit associations so that they are able to purchase and build in attractive urban locations. In negotiations with private developers seeking to obtain planning permissions, the municipality has used planning agreements to secure the provision of a proportion of affordable homes in private market developments. The need for land to build social/affordable housing, which is provided by non-profit housing associations, and the political commitment to promote mixed communities as a way of tackling segregation, have been key drivers of the implementation of this measure.

\section{Methodology}

The research used a qualitative methodology to collect information about the perspectives and meanings participants give to the concept and policies of social mixing. The aim was to understand their beliefs, values, and knowledge concerning these policies. The empirical results presented in this paper are based on 13 semi-structured interviews conducted between May and July 2014 in Copenhagen with individuals with extensive professional experience in housing and urban planning issues. An outline of the interviewees' professional backgrounds, work roles, and institutional affiliations is presented in Table 1.

Table 1 - List of interviewees.

In order to maintain confidentiality and protect the identity of the professionals from whom I gathered information, the list was anonymized and no further details on age, previous jobs, or gender were provided. The interviews were anonymous in order to encourage respondents to be as open and transparent about their views as possible.

The following quotations reveal two insights: if more information were provided this could potentially expose respondents' identities, and the interviewees selected have extensive experiences in common, with professional trajectories consisting of working in multiple organizations and functions (policy-making, implementation, or evaluation of policies).

"Before I worked in private consultancy, later on in the Ministry of Finance, after that I worked for the Minister of Economic Affairs, also as a political adviser."

"I have been working here in the government for 6 years. [...] Before I worked 9 years as a chief planner in the city of Copenhagen."

"I have been in this job only half a year, before I was a director at the city hall working with city planning, first I was in the social department and the last three years in the technical and planning department."

The sampling and recruitment procedure followed a snowball sampling in which the interviewees' recommendations facilitated access to new interviewees. The first interviews were conducted with scholars with long experience in the evaluation of housing and urban regeneration policy. The

to a home that is more suitable than their present abode, and iii) newly divorced individuals who have separated, broken relationships within the past year who need to find accommodation quickly, as long as they already live in Copenhagen. As the system is blind regarding ethnicity, nationality etc., members of ethnic minorities who are employed or studying etc. can move in. Hence the ban is based on integration into the labour market or education system, not on cultural, religious, or racial criteria. 
interviewees were invited to identify other people with experience in consultancy, policy-making, implementation, or evaluation of programmes. All were invited to participate through email. Formal emails that were sent to the local authority in Copenhagen, namely to the departments that deal with housing and urban issues, requiring the scheduling of interviews, were answered within a few weeks. Invitations followed all the ethical concerns related to research practice (explanation of the aims and methods of the study and issues of consent and confidentiality). The respondents were informed that interviews would be: recorded digitally and subsequently transcribed; anonymity would be protected, and the project was being undertaken in the context of academic research.

The topic guide was made up of open questions and a loose structure, drafted in such a way as to allow participants the opportunity to voice their opinions, viewpoints, and attitudes towards the meanings of social mixing, in particular regarding the main types and causes of segregation and policies to overcome segregation in Copenhagen. The location of the interviews was decided by the interviewees in order to make them feel comfortable, in some cases, their own houses, others their workplaces. All interviews were digitally recorded with the permission of each interviewee, anonymized, and subsequently transcribed. In terms of data analysis, I used a thematic approach to examine all the data and identify the main themes and topics that would provide an overview of all the perspectives. The coding strategy was data-driven, that is, codes were derived from the words/phrases used by respondents (examples of codes included meanings of the concept of social mixing, policies/initiatives to address segregation, competing opinions about outcomes). The data was marked and coded, and afterwards extracts were taken from their original context and organized into categories by code.

Drawing upon qualitative data from a few cases, the article does not aim to generalize the results from a statistical point of view. On the contrary, the logic is exploratory, aiming to bring the researcher's gaze as close as possible to the insider's perspective, that is, the meaning actors give to their practices (primarily planners, but also other stakeholders who cooperate with them). In this regard, it is worth recalling the contextual embeddedness of planning action, as the planning system itself (given its own specific rules and resources), is an object of interpretation and selective application by actors (Reimer \& Blotevogel 2012).

The patterns and relationships found under the themes and topics analysed in interviews are discussed below.

\section{Results}

\section{Understanding the concept of social mix}

In answer to the question 'What's your idea of social mix?', whilst some respondents claimed that the concept of social mixing is problematic, arguing that it is rather vague as there are several different criteria to define it (ethnicity, race, religion, income, and housing tenure) (E5, E12), others argued that the concept is linked to a desire to promote tenure mix and counteract residential segregation (E8, E3). Whereas most interviewees defined the concept with reference to ethnic, educational, and income parameters (E7, E6, E10), or as a balance between social groups, some defined it in relation to housing tenure, claiming that a mix of different tenures and housing types is seen to contribute to a heterogeneous social structure (E2, E8).

Two interviewees noted that there is no detailed understanding or explanation of why social mixing works and why it performs any service $(E 5, E 12)$. They claimed that there is only a general idea that if 
segregation is bad then social mixing must be a good thing, but there is no proper understanding of what it means, or how it works in detail. Furthermore, it was claimed that there is no irrefutable evidence to support the notion that a particular social mix is better than no social mix (E5). The relative importance of the neighbourhood of work versus that of residency and how this affects social contact and individual fortunes (e.g. income levels, and social mobility) was emphasized by the same interviewee:

\begin{abstract}
In the first place, you may wonder if segregation means anything, because the measure of segregation depends on where you live. For example, I live in an upper middle class area, but when I am there I am mostly at home ( asleep). At work I am in one of the poorest neighbourhoods in the whole city (Sydhavn) and here I do not mix with other people, because we have separation of different social groups and functions. (E5).
\end{abstract}

Municipal planners interviewed spoke positively about the benefits of mixing building types and tenures as a means of avoiding concentrations of poverty and social exclusion (E7, E11). All seem to agree that the residential concentration of families with fewer resources hinders opportunities of social integration and amplifies processes of stigmatization and urban decay. As a practical tool to prevent or counteract urban decay and make living conditions in deprived neighbourhoods easier, social mixing was emphasized by several interviewees who also noted that geographical patterns of disadvantage are the result of social processes operating over space, under different conditions, for example, in terms of access to services, workplaces, or social relations.

Another interviewee (E4) emphasized the importance of the scale on which the social mix occurs, noting that it is one thing to generate it in the same building and another, in a wider perspective, to create a mix of different tenures with meeting places where there is more room for diversity (cf. parks, playgrounds, libraries, schools, childcare institutions).

\footnotetext{
A friend of mine moved from Nørrebro, where you have a mix of housing and families (ethnic minorities, Danish families, alcoholics etc.) to $\emptyset$ sterbro and he said: 'I have to admit I was fed up with the mix, I had to move where people are more like me.' He was a bit embarrassed that he felt that because he always preached mix, teaching his kids that mix is good! I think the main problem is that the area in Nørrebro is too small, so the mix is going on in a very narrow area. The good thing is that when we develop new areas we have to be sure that there is a housing mix and then make communal areas, but not necessarily force people to live next door, because I think everyone needs someone to be like them next door in order to feel secure. I also think that is a mistake if we make rich and poor ghettos. (E4).
}

Similar opinions are expressed in the literature. For example, Lees (2008) writes that: "My feeling is that if people prefer to live with people like themselves we should not be forcing them to mix, because ultimately this will fail; rather, we should be keeping the possibility for mixing open to them".

Other interviewees commented on how social processes play out and are influenced by the geography of space, emphasizing the issue of the spatial concentration of needy people and school segregation (E9, E10). One interviewee (E8) noted that the more mixed neighbourhoods are, the more energy people often put into searching for private schools. Whilst in well-off, more homogeneous areas, they prefer public schools, emphasizing the overwhelming tendency among middle class parents in mixed communities to avoid schools with high concentrations of low-income and/or minority ethnic children.

For instance, in the inner-city district of Nørreport most Danish students are now attending a private school. This goes also for immigrant kids, because they don't want to go to the bad public schools, so they go to private Muslim schools. They live very close, they meet in the street, but they live in separate worlds (E8).

Trends of school segregation are confirmed by statistical data. Rangvid (2007) shows that in Copenhagen, where about $30 \%$ of all residents aged 6-15 come from an immigrant background 
(Rangvid 2007), owing to the choice of school (whether public or private sector), levels of school segregation have increased. According to her, "for some student groups, segregation at the school level in Copenhagen reaches levels comparable to the high/extreme segregation levels experienced by many US cities" (Rangvid, 2007: 1330), which is seen to impact negatively on the acquisition of Danish and on the construction of ties between social groups.

Several interviewees noted that the concentration of poverty and social exclusion makes it more difficult to accommodate the needs of vulnerable populations, and the coexistence of people from different ethnic and cultural backgrounds becomes fraught. Whilst social interaction might be easier in homogeneous neighbourhoods, between individuals who are more similar, the concentration of underprivileged groups on some non-profit estates makes for difficult coexistence, creating additional problems of stigma and bad reputation. Planners and administrators seem to be concerned with problems of crime, insecurity, conflicts, and physical deterioration that are observed in neighbourhoods where a concentration of social problems reinforces trends of segregation and further concentration of disadvantage.

\section{Concerns and assumptions underlying ideas of social mix and mixed communities}

To the question 'What type of segregation do you believe to be the most problematic in Copenhagen (demographic, socio-economic, ethnic, or a combination of these)?', most stakeholders indicated that they are closely interrelated, and it is not possible to separate them. Some established a relation between ethnic and socio-economic segregation, but focused mainly upon socio-economic segregation (E8, E13). Most claimed that socio-economic inequality is the most problematic and is increasing in Copenhagen. According to one interviewee (E11), the ethnic question has become a part of the segregation problem in Copenhagen over the last 20 years or so, noting that in some areas there is an overlap of economically disadvantaged neighbourhoods and concentrations of ethnic minorities.

Other interviewees explained with examples how issues of segregation/social mix can affect the integration and daily life of inhabitants, noting from different perspectives that residential proximity creates encounters and encourages social interaction (E3, E4, E12). Whilst some emphasized that, when perceived positively by individual households, the residential proximity of families belonging to the same social group (ethnicity, income etc.) favours the development of relationships of solidarity and cooperation (E1, E12), others noted that the concentration of families with fewer resources can be problematic, for example, from the perspective of the management or maintenance of these neighbourhoods, noting that tenant satisfaction is usually lower in those areas (E9, E10).

\footnotetext{
I have talked with some of the women in Mjølnerparken and the thing we see out there is that many people have lived there for many many decades (they came as refugees and stayed for decades) and there is a very good network between residents (Somalis and Palestinians), but they are ethnically segregated. They were traditionally non-communicative but they have gradually opened up. They feel more secure in the same ethnic group. Some of the people have networks outside, others don't. Among the first generation, many women speak very bad Danish, so you can only have friends among your ethnic group. It is different in the second generation. They meet together at school and they have a common language. Some are very strong, especially the girls, but they also have energy in the sense that they take care of their families and remain with their families, so it would be interesting to hear girls speak of their future plans, where they want to live etc. (E4)
}

According to interviewees, the major reasons for strategies of social mix are to avoid ghettoization associated with the over-representation of underprivileged groups on some non-profit estates, (namely people with mental illnesses or fewer resources), therefore reduce stigma and the poor 
reputation of some neighbourhoods. Another reason is to avoid major socio-economic differences between areas, and between those who have more and others with less income. As a CEO at a nonprofit housing association with a background in economics explained, while inequality fuels conflict, feelings of uncertainty and lack of security, a mix of private and public housing and amenities would promote a better city.

Support for social mix is also based on the premise that social groups can be disadvantaged by the place where they live (cf. networks, reputation, job opportunities), so the idea of taking specific action to change their social composition is seen as positive.

If you look at a city and look at all the economic forces that there are in a city, you can see that if there is no regulation, rich people will choose the best and most exciting places and poor people will live in the worst places. Therefore, you need to regulate the mix across the city, and you have to mix the city at two levels: function mix (so that you can have a proper distribution of shops, dwellings, and other activities across the city), and social mix. I think they are related (E11).

As one interviewee claimed: "If you want to stop income segregation you will have to stop the flow of poor people coming in to disadvantaged neighbourhoods. You will have to reserve some of the vacant apartments for students, and those who have resources" (E8). The strong correlation between problems of reputation and management of disadvantaged neighbourhoods and the concentration of unemployed families has justified the decision to remedy the problem of social homogeneity and bring a sense of 'normality' to stigmatized neighbourhoods.

In a paper discussing the extent to which ethnic concentration is considered to be a problem addressed by social mix housing and urban renewal policy, Bolt (2009) recognizes that ethnicity has been used as a criterion for housing diversification policy in few countries, the socio-economic criterion being the main justification used to promote a balanced population in allocation policies in the social rented sector. Bolt (2009), who finds that social mix policies fall short of expectations, claims that such policies are based on several erroneous assumptions, such as the significance of neighbourhood as a space in which social practices play out, and the preferences of communities in terms of socializing. Heringa et al. (2017) also claim that certain categories do not really focus upon their neighbourhood for the purposes of social activity and interaction, but prefer socializing with people who are similar in terms of age, social and ethnic background, social status and ambition, feeling alienated and out of place when they are surrounded by people who are 'different'. This claim is not confirmed by other empirical studies. Whilst the voluntary choice of aggregation for the preservation of networks of social support and aspects of cultural or religious identity is widely recognized (Schnell \& Ostendorf, 2002), over-representation of ethnic groups in some areas is also the result of a lack of financial and cognitive resources that limits their political and social power in society (see also Doucet \& Koenders 2018). Peral and Ramos (2014) identify diverse forms of ethnic or cultural discrimination towards people perceived to belong to different racial or ethnic groups.

\section{Policies and initiatives that promote area-based and city-wide social mixing}

The previous section explores the understanding of social mixing and social segregation in the context of Copenhagen. This section explores the measures that have been used to promote social mixing in the context of new developments and disadvantaged neighbourhoods. Two interviews (E7, E11) were carried out in the Department of Technical and Environmental Administration, in Copenhagen municipality which is responsible for matters of local planning, urban regeneration, and environmental issues. Therefore, it is responsible for the formulation and implementation of the city's area-based and community regeneration programmes and for cooperation with non-profit 
housing associations. I also interviewed two professionals who worked in this department but later moved to the non-profit sector and the central state (E3, E8).

Invited to identify, describe, and comment on initiatives that aim to promote social mixing, interviewees referred to two types of initiative in particular. One typology targets new developments and uses everyday planning activities to promote more diverse housing structures at the local level. This includes land-use policies and site-by-site negotiations and planning agreements between the local authority and private developers who seek planning permission for new urban developments.

There is a great deal of pressure to follow market wishes but because plots are so scarce in Copenhagen we are in the luxurious position of being able to make a number of demands through our planning authority. That is also a political priority. We negotiate the public interest which is done not by force but by bilateral agreements. They want municipal cooperation in planning, authorization to build, and we negotiate a particular amount of social housing. Let me give you a good example. The Carlsberg area (which is a great location, close to parks, Vesterbro, and so on). Because Carlsberg is moving their production to another area, the whole area has been going through a huge transformation process. The Carlsberg people approached the municipality, obviously because they need planning permission for the development of that area, and then we typically made what we call a 'City Development Agreement', which is a bilateral agreement that says what our general expectations of the area are, for example, how much housing can be built in the area, the percentage that has to be for social housing, and so on. This is how we get good locations for social housing. Afterwards, they invite someone or have a competition to work with them. We usually say they have to work with different partners; in Carlsberg there are three social non-profit organizations. That is also how we get variation in the social types. (E11).

The other typology targets disadvantaged areas. It involves social and physical plans for disadvantaged areas and a system of 'flexible allocation' that gives those in employment and students priority (independent of their national or ethnic background) in the vacant dwellings of disadvantaged areas. The ineffectiveness of previous efforts of urban regeneration to tackle income segregation, bad reputation, and cycles of neighbourhood decline (E10) has been used to justify this measure of reducing the influx of poor newcomers to a few disadvantaged neighbourhoods.

When there are more than $40 \%$ of people outside the labour market, we halt the influx of people from the municipality waiting list, and there is only access through the ordinary waiting list. This is what we call 'flexible allocation rules for renting'. It basically means that if you have a job or are under 35 or over 55, or recently divorced, then you can skip the list and go to areas we usually consider socially disadvantaged. This is a great tool to move students to these disadvantaged areas where they can contribute to raise the standard of these areas. Kids can see this guy goes to university etc. (E7).

Regarding the use of the planning system to secure affordable housing in new developments (the first typology of initiative), negotiations at the municipal level do not involve a specific national law in Danish legislation. The implementation of this long-term goal of creating a mixture of tenures in all areas depends, therefore, upon the local actors' commitment and ability to negotiate and bargain with the private sector. Informants made the point that there are good instruments in Denmark for the provision of social housing, noting that they are very well financed and organized, but lamented the lack of tools in the planning system at the local level to force the private owner to build social housing in the most attractive areas, where non-profit associations find it difficult to purchase and build housing.

It is very important that politicians have tools - this is my personal view. I think you need to have some tools when you want to negotiate. Perhaps you don't have to use them all the time, but it is easier to say we have these tools to get planning permission (E8).

The situation of those in a socio-economically weak position, who no longer find housing in the regenerated areas and in areas subject to flexible allocation rules, was a theme discussed by respondents concerned with the fact that small cheap apartments are disappearing in Copenhagen. 
As emphasized by one interviewee: "if public housing was converted into cooperatives, old neighbourhoods are renewed with more expensive housing units, and if building new and cheap social housing is no longer possible, then where are the low-income households to live?" (E5). The lack of affordable housing for people at the edge of the housing market is considered to be a challenging issue for the public sector in Copenhagen today, as families with fewer resources find it difficult to find options in the city.

To sum up, interviewees were unanimous in agreeing that, as the building rights are allocated through spatial planning, using plans that regulate the landowner's right to use and develop land (implementing infrastructure, construction), the principle of tenure mix is a good tool to secure affordable housing in new developments. The development of housing using a non-market-based approach by non-profit housing associations that are deeply rooted in a Danish welfare policy aiming to limit housing inequality across class and the city is considered to be essential to the provision of more affordable housing for low and moderate-income households.

\section{Conclusion}

This section is structured in two parts. The first is general, drawing on a critical analysis of the international literature review on social mix and segregation, the second is more specific and focuses more directly upon the results gleaned from interviews.

The debate around class, ideology, and the production of housing and the built environment has shown how housing is provided and managed by the state, in cooperation with private and nonprofit actors, and influences processes of class formation. Spaces in which people live and work affect their material wellbeing, social relations (opportunities for solidarity, preservation, and affirmation of cultural identities), and opportunities for social integration. Whilst social segregation has been used to sustain and reinforce inequality, the transformation of traditionally residential working-class areas into middle-class neighbourhoods has also been used to facilitate market interests which in many cases damage the social fabric and are not in the interests of the poor (Pugalis 2016).

However, policies of social mix are not all the same, either in the assumptions they make or in the way they are formulated and implemented locally. The advantages and disadvantages of these policies are widely identified in the literature, as well as the reasons that seem to support or oppose them. The results presented in this paper seem to suggest the importance of social mix policies, on the one hand to prevent and counteract processes of segregation and urban decay (that is, the concentration of less well-resourced families in some neigbourhoods), and, on the other to foster the delivery of more affordable housing. In a context in which property speculators and neoliberal housing policies have raised house prices and problems of housing affordability are a major political challenge, the idea of making room for affordable housing in each new development and especially where such accommodation is less present seems to make lot of sense.

Interviews conducted in Copenhagen with government, local officials, and academics generated a number of results.

First, efforts to create social mix or mixed communities are a component of policies in the fields of spatial planning, urban regeneration, and housing policy, and have been applied both to existing disadvantaged neighbourhoods and new housing developments. While these policies may seek to achieve objectives of social justice (ensuring that families with modest resources have access to 
attractive urban locations), and of spatial justice (ensuring that inequality between territories is reduced), its success depends upon the ability to create a diverse housing structure, with opportunities for all types of household across the city.

Second, in Copenhagen strategies that target disadvantaged neighbourhoods have not involved the sale and/or demolition of dwellings or the displacement of families, but a system of flexible allocation to vacant dwellings that aims to reduce the concentration of unemployed and low-income tenants.

Third, there is a general consensus that the universalist orientation of social and housing policy should be maintained. The central element of such policies is that access to non-profit housing should not be limited to any particular social group but should be open to all citizens independent of income. The exception to this rule is disadvantaged neighbourhoods where a system of flexible tenant allocation has sought to foster a more balanced social composition of residents.

Fourth, a key concern related to strategies of social mix revolves around whether changes in neighbourhood characteristics (regarding employment, educational attainment, or income) will also be emphatically pursued in affluent neighbourhoods, and if policies will be able to deliver enough new affordable housing to those in the worst conditions. The transformation of obsolete dwellings into modern and attractive housing has in turn led to the transformation of tenures and costlier housing that, even given housing subsidies to persons and families on low incomes, makes it difficult to access renovated housing. A major concern is if residents who have no income from work and pensions are able to find accessible and affordable housing in Copenhagen.

Finally, the interviews show that even in countries such as Denmark where instruments of inclusionary housing have not been made available at the national level, planners and other groups of actors at the local level (e.g. from the public and non-profit sectors) can use the principle of social mix to foster the provision of affordable and not-for-profit rents.

The results of this study emphasize the need for more context and more sensitive analysis of ideas and practices of social mix. The fact that the debate on social mix has been highly polarized and has over-emphasized traumatic experiences related to demolition and forced evictions should not mean that ideas of social mix are not given proper consideration regarding the contribution they might make to spatial planning and housing policy. The results also emphasize the need to distinguish between social mix as a programme of intervention to tackle urban decay and segregation, and a land-use planning tool to secure land for the provision of affordable housing.

\section{References}

Allen, C., Powell, R., Casey, R, Coward, S. (2007) 'Ordinary, the Same as Anywhere Else' Notes on the Management of Spoiled Identity in 'Marginal' Middle-Class Neighbourhoods, Sociology, 41 (2), pp. 239-258.

Alves, S. (2015) Welfare State Changes and Outcomes: the Cases of Portugal and Denmark from a Comparative Perspective. Social Policy \& Administration, 49(1), pp. 1-23.

Alves, S. (2016), 'Spaces of inequality: It's not differentiation, it is inequality! A socio-spatial analysis of the City of Porto', Portuguese Journal of Social Science, 15: 3, pp. 409-31, doi:

10.1386/pjss.15.3.409_1 
Alves, S (2017a) Assessing the impact of area-based initiatives in deprived neighborhoods: The example of S. João de Deus in Porto, Portugal. Journal of Urban Affairs, Vol. 39 (3), pp. 381-399.

Alves, S (2017b) Poles Apart? A Comparative Study of Housing Policies and Outcomes in Portugal and Denmark. Housing, Theory and Society Vol. 37, 2, 221-248.

Andersen, H. T. (2012) The solidity of urban socio-spatial structures in Copenhagen, Maloutas, T., \& Fujita, K., Residential Segregation in Comparative Perspective: Making Sense of Contextual Diversity, Ashgate, p. 177-196

Andersen, H. T., Blach, V., Nielsen, R. S., \& Beckman, A. W. (2014) Assessment of Urban Policies on Diversity in Copenhagen, Copenhagen: Danish Building Research Institute, Aalborg University.

Andersson, E., Malmberg, B., Costa, R., Sleutjes, B, Stonawski, M., Valk, H. (2017) A Comparative Study of Segregation Patterns in Belgium, Denmark, the Netherlands and Sweden: Neighbourhood Concentration and Representation of Non-European Migrants, ResSegr Working Paper.

Andersson, R., Bråmå, Å. \& Holmqvist, E. (2010) Counteracting segregation: Swedish policies and experiences. Housing studies 25 (2), pp. 237-256.

Arthurson, K. (2008) Australian Public Housing and the Diverse Histories of Social Mix, Journal of Urban History, vol. 34 (3), pp. $484-501$.

Arthurson, K. (2012) Social Mix and the City: Challenging the Mixed Communities Consensus in Housing and Planning Policies, Collingwood: CSIRO, Australia.

Arthurson, K., Levin, I, \& Ziersch, A. (2015) What is the Meaning of 'Social Mix'? Shifting perspectives in planning and implementing public housing estate redevelopment, Australian Geographer, vol. 46 (4), pp. 491-505.

Birk, R. H. (2017) Infrastructuring the social: Local community work, urban policy and marginalized residential areas in Denmark, Environment and Planning A, Vol 49 (4), pp. $767-783$.

Bolt, G. (2009) Combating residential segregation of ethnic minorities in European cities, Journal of Housing and the Built Environment, 24, pp. 397-405.

Bolt, G., \& van Kempen, R (2013). Introduction special issue: Mixing neighbourhoods: Success or failure? Cities, 35, 391-396.

Blanc, M. (2010) The Impact of Social Mix Policies in France. Housing Studies, 25 (2), pp. 257-272.

Bourdieu, P. (1999) Site effects, in Bourdieu et al. (eds). The Weight of the World: Social suffering in Contemporary Society. Cambridge: Polity Press, 123-129.

Bridge, G., Butler, T. \& Le Galès, P. (2014) Power Relations and Social Mix in Metropolitan Neighbourhoods in North America and Europe: Moving Beyond Gentrification?, International Journal of Urban and Regional Research, 38 (4), pp. 1133-1141.

Carter, H., Larsen, H. G. \& Olesen, K. (2015). A Planning Palimpsest: Neoliberal Planning in a Welfare State Intervention, European Journal of Spatial Development, 58, pp. 1-20.

Cole, I., \& Etherington, D. (2005) Neighbourhood renewal policy and spatial differentiation in housing markets: recent trends in England and Denmark. European Journal of Housing Policy, 5(1), pp. 77-75. 
Colomb, C. (2007) Unpacking new labour's 'Urban Renaissance' agenda: Towards a socially sustainable reurbanization of British cities?, Planning Practice \& Research, 22(1), pp. 1-24.

Christensen, G. (2015) A Danish Tale of Why Social Mix Is So Difficult to Increase, Housing Studies, 30(2), pp. 252-271.

Engberg, L. and Larsen, J. N. (2010) Context-Orientated Meta-Governance in Danish Urban Regeneration, Planning Theory \& Practice, Vol. 11 (4), pp. 549-571.

Fainstein, S. (2005) Cities and diversity should we want it? Can we plan for it? Urban affairs review, 41(1), pp. 3-19.

Fincher, R., Iveson, K., Leitner, H., \& Preston, V. (2014) Planning in the multicultural city: Celebrating diversity or reinforcing difference? Progress in Planning, 92, pp. 1-55.

Galster, G. \& Friedrichs, J. (2015) The Dialectic of Neighborhood Social Mix: Editors' Introduction to the Special Issue, Housing Studies, 30 (2), pp.175-191.

Galland, D. (2012) Understanding the Reorientations and Roles of Spatial Planning: The Case of National Planning Policy in Denmark, European Planning Studies, 20 (8), pp. 1359-1392.

Giddens, A. (1984) The Constitution of Society, Outline of the Theory of Structuration, Cambridge: Polity Press.

Hansen, A. L., Andersen, H. T., \& Clark, E. (2001) Creative Copenhagen: globalization, urban governance and social change, European Planning Studies, 9(7), 851-869.

Heringa, A., Bolt, B. \& Dijst, M. (2017): Path-dependency in segregation and social networks in the Netherlands, Social \& Cultural Geography, DOI: 10.1080/14649365.2017.1301541

Holmqvist, E. and Bergsten, Z. (2009) Swedish social mix policy: a general policy without an explicit ethnic focus, Journal of the Housing and the Built Environment, 24, pp. 477-490.

Jensen, T. G. (2016) Neither trust nor distrust: Social relations in a multi-ethnic neighbourhood in Copenhagen. Nordic Journal of Migration Research, 6 (1), pp. 25-32.

Jensen and Stensgaard (2016) Creating Affordable Housing through self-management: Experiences from a Danish concept, Paper presented at Boligforskerseminar, København.

Joans, Hans and Knobl, Wolfgang (2009) Social Theory. Twenty Introductory Lectures, Cambridge: Cambridge University Press.

Jørgensen, G, Ærø, T. (2008) Urban Policy in the Nordic Countries-National Foci and Strategies for Implementation. European Planning Studies, 16 (1), pp. 23-41.

Le Galès, P. and Therborn, G. (2009), 'Cities', in S. Immerfall and G. Therborn (eds), Handbook of European Societies: Social Transformations in the 21 $1^{\text {st }}$ Century, New York, NY: Springer, pp. 59-89.

Lees, L. (2008) Gentrification and Social Mixing: Towards an Inclusive Urban Renaissance?, Urban Studies, 45 (12), pp. 2449-2470.

Lelévrier, C. (2013) Social mix neighbourhood policies and social interaction: The experience of newcomers in three new renewal developments in France. Cities, 35, pp. 409-416. 
Malheiros, J., Carvalho, R., \& Mendes, L. (2013) Gentrification, residential ethnicization and the social production of fragmented space: a comparison between two multi-ethnic neighbourhoods in Lisbon and Bilbao. Finisterra: Revista Portuguesa de Geografia, 48 (96), pp. 109-135.

Manley, D., \& van Ham, M. (2012) Neighbourhood effects, housing tenure and individual employment outcomes. In Neighbourhood effects research: New perspectives. Springer Netherlands, pp. 147-173.

Monk, S., Clarke, A. \& Tang, C. P. Y (2011) Mixed Communities Literature Review. Scottish Government Social Research, The Scottish Government.

Morrison, N., \& Burgess, G. (2014) Inclusionary housing policy in England: the impact of the downturn on the delivery of affordable housing through Section 106. Journal of Housing and the Built Environment, 29(3), pp. 423-438.

Munk, A (2007) Ten years of Integrated Urban Regeneration, KVARTERLØFT 10 Years of Urban Regeneration, edit by Jensen, E. and Munk, A., The Ministry of Refugees, Immigration and Integration Affairs, pp. 9-12.

Münch, S. (2009) It's all in the mix": constructing ethnic segregation as a social problem in Germany, Journal of Housing and the Built Environment, 24 (4), pp. 441-455.

Musterd, S. \& Ostendorf, W. (2012) Inequalities in European cities. In International encyclopedia of housing and home, ed. S. J. Smith, M. Elsinga, L. F. O'Mahony, O. S. Eng, S. Wachter, and D. Clapham. Oxford, UK: Elsevier, pp. 49-55.

Municipality of Copenhagen (2011) Policy for Disadvantaged Areas, The Technical \& Environmental Administration. Accessed at: http://kk.sites.itera.dk/apps/kk_pub2/pdf/869_yNq8vh4bJF.pdf, 29 May 2016.

Larsen, J. N., \& Nørgaard, H. (2003) From slum clearance and housing renewal to networking and area-based approaches on the origins of contemporary Danish urban development programmes. Garant: Antwerp, pp. 43-57.

Larsen, H. G., \& Hansen, A. L. (2008) Gentrification-gentle or traumatic? Urban renewal policies and socioeconomic transformations in Copenhagen. Urban Studies, 45 (12), pp. 2429-2448.

Kearns, A., M.cKee, M. J., Sautkina, E., Cox, J. \& Bond, L. (2013) How to mix? Spatial configurations, modes of production and resident perceptions of mixed tenure neighbourhoods", Cities, 35, pp. 397408.

Kilminster, R. (2013) Critique and overcritique in sociology, Human Figurations: Long-term Perspectives on the Human Condition, 2 (2), Permalink:

http://hdl.handle.net/2027/spo.11217607.0002.205

Kristensen, H. (2002) Social housing policy and the welfare state: a Danish perspective. Urban Studies, 39(2), pp. 255-263.

Peral, E. B. \& Ramos, A. (2014) Neighbours: determinants of whom Europeans want to keep a distance. In Arts, W., Halman, L. (Eds.), Value contrasts and consensus in present-day Europe: painting Europe's moral landscapes (pp. 117-141). Leiden: Brill.

Pugalis, Lee (2016) Austere State Strategies: Regenerating for Recovery and the Resignification of Regeneration. Local Government Studies, 42 (1), pp. 52-74. 
Rangvid, B. S. (2007) Living and learning separately? Ethnic segregation of school children in Copenhagen. Urban studies, 44 (7), pp. 1329-1354.

Reimer, M. \& Blotevogel, H. (2012) Comparing Spatial Planning Practice in Europe: A Plea for Cultural Sensitization, Planning Practice and Research, 27 (1), pp. 7-24.

Rose, D., Germain, A., Bacqué, M. H., Bridge, G., Fijalkow, Y., \& Slater, T. (2013) 'Social Mix'and Neighbourhood Revitalization in a Transatlantic Perspective: Comparing Local Policy Discourses and Expectations in Paris (France), Bristol (UK) and Montréal (Canada). International Journal of Urban and Regional Research, 37(2), pp. 430-450.

Sarkissian, W. (1976) "The Idea of Social Mix in Town Planning: An Historical Review", Urban Studies, 13 (23), pp. 1-246.

Savage, M., Cunningham, N., Devine, F., Friedman, S., Laurison, D., Mckenzie, L., Miles, A., Snee, H. and Wakeling, P. (2015) Social Class in the 21st century, Penguin Books.

Selim, G. (2015) The landscape of differences: Contact and segregation in the everyday encounters. Cities, 46, pp. 16-25.

Schnell, I. \& Ostendorf, W. (2002) Studies in segregation and desegregation. London, Ashgate Publishing.

Sørvoll, J. \& Bengtsson, B. (2018) Mechanisms of Solidarity in Collaborative Housing - The Case of Co-operative Housing in Denmark 1980-2017, Housing, Theory and Society, DOI:

10.1080/14036096.2018.1467341

Skifter-Andersen, H. (2002) Can Deprived Housing Areas Be Revitalised? Efforts against Segregation Neighbourhood Decay in Denmark and Europe. Urban Studies, 39 (4), 767-790.

Skifter-Andersen, H. (2012) Housing policy in the Nordic countries and its implication for the housing of immigrants. Danish Building Research Institute, Aalborg University.

Skifter-Andersen, H. (2016) Selective moving behaviour in ethnic neighbourhoods: white flight, white avoidance, ethnic attraction or ethnic retention? Housing Studies, DOI:

10.1080/02673037.2016.1208161.

Tersteeg, A. K. \& Pinkster, F. M. (2015) "Us Up Here and Them Down There": How Design, Management, and Neighbourhood Facilities Shape Social Distance in a Mixed-Tenure Housing Development, Urban Affairs Review, pp. 1-29.

Wacquant, L., Slater, T., \& Pereira, V. B. (2014). Territorial stigmatization in action, Environment and Planning A, 46 (6), pp. 1270-1280.

Wacquant, L. (2018) Bourdieu comes to town: Pertinence, Principles, Applications, International Journal of Urban and Regional Research, 42 (1), pp. 90-105.

Warr, D., Davern, M., Mann, R. \& Gunn, L. (2017) Diversifying Experiences of Community and the Implications for Addressing Place-based Poverty, Urban Policy and Research, 35:2, 150-164.

Wessel, T. (2009) Does diversity in urban space enhance intergroup contact and tolerance? Geografiska Annaler: Series B. Human Geography, 91 (1), pp. 5-17.

Young, I. M. (2002) Inclusion and democracy. Oxford: University Press Scholarship Online. 
Ziersch, A., Arthurson, K \& Levin, I. (2018) Support for tenure mix by residents local to the Carlton Housing Estate, Melbourne, Australia, Housing Studies, 33:1, pp. 58-76. 